\title{
Clinical Observation of the Efficacy of Endoscopic Retrograde Cholangiopancreatography on Elder Choledocholithiasis and Its Effects on the Levels of TNF- $\alpha$, IL-1, and IL-6
}

\author{
Yun-zhi Shen ${ }^{\mathbf{1}, \#}$ \\ Xiao-hui Peng,\# \\ Yu Bai \\ Bin Xiong ${ }^{3}$ \\ Ping Che ${ }^{4}$ \\ De-quan Jiang ${ }^{5}$
}

\begin{abstract}
1. Tianjin third central hospital, liangjin district, Chongqing, China 2. Department of general surgery, Fifth Hospital of Xiamen, Jiangjin district, Chongqing, China 3. Department of hepatobiliary surgery, the Second Hospital Affiliated to Chongqing Medical University, Jiangjin district, Chongqing, China 4. Department of hepatobiliary surgery, the people's Hospital of Chongaing Hechuan, Jiangiin district, Chongaing, China 5. Department of the second lesion of general surgery, Jiangjin central hospital of Chongqing, Jiangjin district, Chongqing, China. \# These authors contributed equally to this article.
\end{abstract}

http://dx.doi.org/10.1590/1806-9282.64.11.1012

\section{SUMMARY}

OBJECTIVE: We conducted this study to investigate the clinical efficacy of endoscopic retrograde cholangiopancreatography (ERCP) on elder choledocholithiasis and its effects on the levels of TNF- $\alpha, I L-1$, and IL-6.

METHODS: Elder patients with choledocholithiasis were enrolled in this study, and according to the surgical methods, they were divided into the ERCP group and the surgical group. After treatment, we compared the efficacy of these two methods on patients, inflammatory responses indicated by the levels of TNF- $\alpha, I L-1$, and IL-6, and the complications.

RESULTS: No statistical significance was identified in the difference of the success rate in removal between the two groups (98\% vs. $94 \%)$, but indicators of the ERCP group, including the surgical duration (28.5 \pm 12.8$)$ min, remission duration of abdominal pain (1.2 \pm 0.2$)$ $d$, recession time of jaundice $(2.0 \pm 0.3) d$, postoperative bedridden time $(1.4 \pm 0.2) d$, treatment time of the anti-infection (1.5 \pm 0.2$) d$, length of stay in hospital (6.5 \pm 0.3$) \mathrm{d}$, levels of TNF- $\alpha(2.1 \pm 0.2) \mu \mathrm{g} / \mathrm{L}, \mathrm{IL}-1(6.3 \pm 0.8) \mu \mathrm{g} / \mathrm{L}, \mathrm{IL}-6(2.8 \pm 0.3) \mu \mathrm{g} / \mathrm{L}$, and the incidence rate of complications (1.8\%), were all significantly lower than those in the surgical group $(p<0.05)$.

CONCLUSION: In the treatment of choledocholithiasis, ERCP is excellent in controlling the trauma, accelerating the recovery duration, reducing the occurrence of complications and ameliorating the inflammatory responses. Thus, it is an ideal choice for choledocholithiasis. KEYWORDS: Choledocholithiasis. Cholangiopancreatography, endoscopic retrograde. Tumor necrosis factor-alpha. Interleukin-1. Interleukin-6.

\section{INTRODUCTION}

As a common disease in the biliary system, choledocholithiasis usually leaves severe trauma even the obstruction can be resolved effectively through choledocholithotomy, resulting in a poor tolerance for elder patients. Endoscopic retrograde cholangiopancreatography (ERCP) and endoscopic sphincterotomy (EST) are the major methods with minimal invasions for treatment of choledocholithiasis and 
have shown a variety of advantages, like a high efficiency in removal of calculus, minimal trauma, a low incidence of complications and short length of stay in hospital ${ }^{1,2}$. In this article, we investigated the clinical efficacy and safety of endoscopic retrograde cholangiopancreatography in the treatment of elder choledocholithiasis, and the detailed information is reported as follow:

\section{DATA AND METHODS}

\subsection{Clinical data}

A total of 100 elder patients who were diagnosed as choledocholithiasis in this hospital between May 2016 and May 2017 and had the surgical indications were enrolled in this study. Among these patients, there were 73 males and 27 females aged between 61 and 78 years old with an average of $(68.1 \pm 8.6)$ years old. After admission, they underwent CT or MRCP, through which they were diagnosed as choledocholithiasis, and the diagnoses were all confirmed by the ERCP. According to the surgical methods, they were divided into the ERCP group and the surgical group, and the differences in the demographic data, complications, and type, diameter and number of calculus showed no statistical significance ( $p>0.05$; Table 1$)$.

\subsection{Treatment}

1.2.1 ERCP group

Under non-intratracheal intubation anesthesia, duodenoscope was inserted through the mouth, stomach to get into the duodenum, where the major papilla was found in the descending segment. Guided by the guiding wire, sphincterotome was used for biliary cannulation, and then the contrast agent was injected to clarify the size, position, and quantity of choledocholithiasis. Papillotomy was performed according to the position of uplift of the papilla and the size of calculus, and the basket was placed to retrieve the calculus under the monitoring of radioactive rays; otherwise, calculus was destroyed mechanically or retrieved after dilation by balloon. For small calculus, balloon was recommended to drag the calculus out. For patients that had too many calculi to remove all at once, it was suggested to repeat the steps above to remove all calculi. After surgery, nasobiliary drainage was placed routinely, and diet was forbidden for $24 \mathrm{~h}$. In addition, patients were monitored closely for 24 to $48 \mathrm{~h}^{3}$.

\subsubsection{Surgical group}

After general anesthesia and pneumoperitoneum, Trocar was inserted appropriately, and the surgical vision of common bile duct was exposed sufficiently using an electrocautery or elastic separating plier. Then, the duct was confirmed to be the bile duct through puncture-aspiration of the bile duct and was cut for calculus removal using lithotomy forceps or choledochoscope. A T tube was inserted into the bile duct that was later sutured. In the Winslons hole, a drainage tube was inserted. After surgery, the routine anti-infection procedure was performed with fluid infusion and hemostasis treatment, and patients were required to undergo routine examinations of blood and liver functions.

\subsection{Observation}

\subsubsection{Treatment}

Treatment was observed through following indicators: success rate of calculus removal, surgical duration, postoperative bedridden time, remission time of abdominal pains, recession time of jaundice, duration of anti-infection treatment, length of stay in hospital and complications; we also compared those indicators between two groups.

\subsubsection{Stress responses}

During the surgery, peripheral blood was collected to detect the levels of TNF- $\alpha$, IL-1, and IL-6 of patients in two groups through ELISA.

TABLE 1 COMPARISON OF THE GENERAL DATA BETWEEN TWO GROUPS ()

\begin{tabular}{|c|c|c|c|c|c|c|c|c|c|}
\hline \multirow[t]{2}{*}{ Group } & \multirow[t]{2}{*}{ Case } & \multirow{2}{*}{$\begin{array}{l}\text { Gender } \\
(M / F)\end{array}$} & \multirow{2}{*}{$\begin{array}{l}\text { Age } \\
\text { (years) }\end{array}$} & \multicolumn{2}{|l|}{ Type of calculus } & \multirow{2}{*}{$\begin{array}{l}\text { Number of } \\
\text { choledocholi- } \\
\text { thiasis }\end{array}$} & \multirow[t]{2}{*}{ Diameter } & \multicolumn{2}{|l|}{ Complications } \\
\hline & & & & $\begin{array}{l}\text { Gall bladder } \\
\text { and common } \\
\text { bile duct }\end{array}$ & $\begin{array}{l}\text { Bile } \\
\text { duct }\end{array}$ & & & $\begin{array}{l}\text { Diabetes } \\
\text { mellitus }\end{array}$ & $\begin{array}{l}\text { Hyper- } \\
\text { tension }\end{array}$ \\
\hline ERCP group & 50 & $37 / 13$ & $68.7 \pm 9.1$ & 33 & 17 & $2.5 \pm 0.3$ & $2.2 \pm 0.1$ & 17 & 21 \\
\hline Surgical group & 50 & $36 / 14$ & $67.1 \pm 8.7$ & 32 & 18 & $2.5 \pm 0.6$ & $2.1 \pm 0.2$ & 18 & 20 \\
\hline
\end{tabular}




\subsubsection{Complications}

After surgery, cases of ERCP-associated complications, effusion surrounding the incision, residue of calculi, infection and fever in two groups were recorded.

\subsection{Statistical analysis}

Statistical analysis was carried out with SPSS 18.0. Measurement data were presented as mean \pm standard deviation (), and t test was applied in comparison. For comparison of the enumeration data, chi-the square test was adopted. $\alpha=0.05$ was set as the inspection level.

\section{RESULTS}

\subsection{Treatment}

In the ERCP group, the surgical duration, remission time of abdominal pains, recession of jaundice, postoperative bedridden time, anti-infection treatment duration and length of stay in hospital were all significantly shorter than those in the surgical group $(\mathrm{p}<0.05$; Table 2).

\subsection{Levels of TNF- $\alpha$, IL-1, and IL-6}

During the surgery, the levels of TNF- $\alpha$, IL-1, and IL-6 in the ERCP group were significantly lower than those in the surgery group ( $<<0.05$; Table 3$)$.

2.3 Comparison of the success rate of calculus removal and complications

In the ERCP group, the success rate of calculus removal was $98 \%$, while the first-time and second-time success rates were $92 \%(46 / 50)$ and $6 \%(3 / 50)$ with no failure in calculus removal; there was one patient with mild pancreatitis that was recovered after 3 days of symptomatic treatment; no ERCP-related complications, like bleeding or perforation events, were observed. In the surgery group, there were 6 patients with fever caused by postoperative infection, 7 patients with effusion surrounding the puncture site of the abdominal wall, and 12 with abdominal pain or dull pain. Comparison of the success rate of calculus removal showed that the difference had no statistical significance ( $p>0.05)$, while the incidence rate of the complications in the ERCP group (2\%) was significantly lower than that in the surgical group $(p<0.01$; Table 4$)$.

TABLE 2 COMPARISON OF THE EFFICACY BETWEEN TWO GROUP()

\begin{tabular}{|c|c|c|c|c|c|c|}
\hline Group & $\begin{array}{l}\text { Surgical duration } \\
\text { (min) }\end{array}$ & $\begin{array}{l}\text { Recession of } \\
\text { jaundice }(d)\end{array}$ & $\begin{array}{l}\text { Remission time } \\
\text { of abdominal } \\
\text { pains }(d)\end{array}$ & $\begin{array}{l}\text { Anti-infection } \\
\text { treatment dura- } \\
\text { tion (d) }\end{array}$ & $\begin{array}{l}\text { Postoperative } \\
\text { bedridden time } \\
\text { (d) }\end{array}$ & $\begin{array}{l}\text { length of stay in } \\
\text { hospital (d) }\end{array}$ \\
\hline ERCP group & $28.5 \pm 12.8$ & $2.0 \pm 0.3$ & $1.2 \pm 0.2$ & $1.5 \pm 0.2$ & $1.4 \pm 0.2$ & $6.5 \pm 0.3$ \\
\hline Surgical group & $103.0 \pm 38.3$ & $4.2 \pm 0.4$ & $2.3 \pm 0.4$ & $3.1 \pm 0.4$ & $3.7 \pm 0.6$ & $12.6 \pm 3.4$ \\
\hline$t$ & 11.583 & 11.269 & 10.493 & 11.476 & 18.736 & 10.843 \\
\hline$p$ & $<0.01$ & $<0.05$ & $<0.05$ & $<0.05$ & $<0.05$ & $<0.01$ \\
\hline
\end{tabular}

TABLE 3 COMPARISON OF THE INFLAMMATORY RESPONSES BETWEEN THE TWO GROUP()

\begin{tabular}{|c|c|c|c|c|}
\hline Group & Case & TNF- $\alpha(\mu \mathrm{g} / \mathrm{L})$ & IL-1( $\mu \mathrm{g} / \mathrm{L})$ & $\mathrm{IL}-6(\mu \mathrm{g} / \mathrm{L})$ \\
\hline ERCP group & 50 & $2.1 \pm 0.2$ & $6.3 \pm 0.8$ & $2.8 \pm 0.3$ \\
\hline Surgical group & 50 & $5.3 \pm 0.7$ & $28.0 \pm 4.7$ & $15.1 \pm 2.3$ \\
\hline$t$ & & 12.753 & 24.692 & 29.486 \\
\hline$p$ & & $<0.05$ & $<0.05$ & $<0.05$ \\
\hline
\end{tabular}

TABLE 4 COMPARISON OF THE SUCCESS RATE OF CALCULUS REMOVAL AND COMPLICATIONS BETWEEN TWO GROUPS

\begin{tabular}{l|l|l|l|l|l|l} 
Group & Case & Success rate & \multicolumn{1}{l}{$\begin{array}{l}\text { Complications } \\
\text { Residual cal- } \\
\text { culus }\end{array}$} & $\begin{array}{l}\text { Effusion } \\
\text { Infection and } \\
\text { fever }\end{array}$ \\
\hline ERCP group & 50 & $49(98 \%)$ & $1(2 \%)$ & & $1(2 \%)$ \\
\hline Surgical group & 50 & $47(94 \%)$ & $5(10 \%)$ & $7(14 \%)$ & $6(12 \%)$ \\
\hline$t$ & & 0.483 & & & $18(36 \%)$ \\
\hline$p$ & & $>0.05$ & & & 13.274 \\
\hline
\end{tabular}




\section{3 - DISCUSSION}

As a common disease in biliary system, choledocholithiasis usually leads to incomplete obstruction in the bile duct, which, with the variations in position, contraction, and movement of the common bile duct, can migrate inside the biliary system, thus giving rise to the intermittent attack ${ }^{4}$. According to its pathogenesis, choledocholithiasis is divided into two types, i.e. the secondary and primary choledocholithiasis: Secondary choledocholithiasis is generated from the gall bladder in a small volume, and quite susceptible to be stuck in ampullar region, thus resulting in acute clinical symptoms; primary choledocholithiasis originates in local part, but the compensate dilation of common bile duct usually curbs its adverse effect, which can prevent the symptoms of acute obstruction ${ }^{5}$. For cases without obstruction in common bile duct, patients present only mild abdominal discomfort or pains; for cases with obstruction, patients may complain about acute angina, or even jaundice in some severe cases; once the disease advances into this stage, clinical symptoms can be alleviated through spasmolysis or anti-infection treatment. For recurrent symptoms or purulency in common bile duct, surgical treatment should be considered ${ }^{6}$.

In clinical practice, sphincterotomy is usually considered for treatment of choledocholithiasis, in which an incision is made on the bile duct to remove the calculus, and obstruction is resolved through drainage by T tube $^{7}$. Nowadays, sphincterotomy has been adopted by many hospitals in China for its advantages like a small invasion. However, suture of the incision in the bile duct is one of the problems to be solved. Besides, sphincterotomy also causes severe trauma to patients, leaving scars or stenosis, and for these cases, patients usually face a bigger risk if they have the recurrence of choledocholithiasis ${ }^{8}$, and the symptoms like abdominal pains, fever or jaundice may require the surgical treatment again ${ }^{9}$. Thus, indications should be fully confirmed before sphincterotomy.

In recent years, many clinical researchers have made a tremendous effort in searching for a new method for treatment of choledocholithiasis with small invasions, so as to avoid the trauma caused by surgery, and benefit the prognosis of patients ${ }^{10}$. ERCP can get into the bile duct through the papillary of the duodenum, where an incision can be made against the size of choledocholithiasis to remove the calculus, thereby resolve the obstruction; thus, ERCP is excellent in mini-invasion and efficiency, and patients can rapidly recover after operation ${ }^{11}$. Through comparison between the two groups, we found that the success rate of the calculus removal in the ERCP group was significantly higher than that in the surgical group, and the surgical duration, postoperative bedridden time, remission time of abdominal pain, recession time of jaundice, duration of anti-infection treatment, and length of stay in hospital were all significantly shorter than those in the surgical group, suggesting a positive value of ERCP in treatment of choledocholithiasis.

To further evaluate the safety of ERCP in the treatment of choledocholithiasis, we observed the inflammatory responses during the operation and the complications after operation. At the time of surgical injury, the release of inflammatory factors could be triggered in response to the tissue injuries. In this study, changing the level of TNF- $\alpha$ was the first to be observed after trauma, which could not only mediate the inflammatory responses, but also involve in the recruitment of the inflammatory mediators; IL-1 and IL-6 are the inflammatory factors directly involved in the injuries ${ }^{12}$. Through comparison of the indicators of inflammatory responses between the two groups, we noted that the levels of TNF- $\alpha$, IL-1, and IL- 6 in the ERCP group were significantly lower than those in the surgical group, reflecting that ERCP results in a milder inflammatory response. Besides, we also observed that the incidence rate of ERCP-associated complications in the ERCP group was lower than that in the surgical group, which showed that ERCP is the most ideal choice for the treatment of choledocholithiasis.

Successful intubation in bile duct is necessary for the ERCP, especially for incarcerated gallstones, giant calculus or complications of acute cholangitis, for which pre-cut sphincterotomy should be considered $^{13}$. Moreover, how to remove the giant calculus confuses the physicians. In this study, endoscopic sphincterotomy was made at the papillary for mechanical lithotripsy, dilation by balloon or direct removal by lithotomy balloon; analysis of the efficacy showed that dilation by balloon following the endoscopic sphincterotomy can significantly increase the efficiency in calculus removal, shorten the removal time and decrease the risk of complications, which, however, also requires abundant clinical experience of the endoscopist ${ }^{14}$. Nevertheless, for elder choledocholithiasis, ERCP is conducive to the control of trauma, recovery, alleviation of inflammatory responses and reduction of the complications, and, thus, it is an ideal treatment method for choledocholithiasis. 


\section{RESUMO}

OBJETIVO: Realizamos este estudo para investigar a eficácia clínica da colangiopancreatografia retrógrada endoscópica (ERCP) na coledocolitíase idosa e seus efeitos nos níveis de TNF- $\alpha$, IL-1 e IL-6.

MÉTODOS: Pacientes idosos com coledocolitíase foram matriculados neste estudo. De acordo com os métodos cirúrgicos, eles foram divididos em grupo ERCP e grupo cirúrgico. Após o tratamento, comparamos a eficácia desses dois métodos em pacientes, respostas inflamatórias indicadas pelos níveis de TNF- $\alpha$, IL-1 e IL-6 e as complicações.

RESULTADOS: Não houve significância estatística na diferença da taxa de sucesso na remoção entre os dois grupos (98\% versus 94\%), mas indicadores do grupo $E R C P$, incluindo a duração cirúrgica $(28,5 \pm 12,8)$ min, duração da remissão da dor abdominal $(1,2 \pm 0,2) d$, tempo de recessão de icterícia $(2,0 \pm 0,3) d$, tempo pós-operatório $(1,4 \pm 0,2) d$, tempo de tratamento da infecção $(1,5 \pm 0,2) d$, duração da internação $(6,5 \pm 0,3) d$, níveis de TNF- $\alpha(2,1 \pm 0,2) \mu \mathrm{g} / \mathrm{L}, \mathrm{IL}-1(6,3 \pm 0,8) \mu \mathrm{g} / \mathrm{L}$, IL-6 $(2,8 \pm 0,3) \mu \mathrm{g} / \mathrm{L}$ e a taxa de incidência de complicações $(1,8 \%)$ foram todos significativamente inferiores aos do grupo cirúrgico $(p<0,05)$.

CONCLUSÃo: No tratamento da coledocolitíase, a ERCP é excelente no controle do trauma, acelerando a duração da recuperação, reduzindo a ocorrência de complicações e melhorando as respostas inflamatórias. Assim, é uma escolha ideal para a coledocolitíase.

PALAVRAS-CHAVE: Coledocolitíase. Colangiopancreatografia retrógrada endoscópica. Fator de necrose tumoral alfa. Interleucina-1. Interleucina-6.

\section{REFERENCES}

1. Osoegawa $T$, Motomura $Y$, Akahoshi $K$, Higuchi N, Tanaka $Y$, Hisano $T$, et al. Improved techniques for double-balloon-enteroscopy-assisted endoscopic retrograde cholangiopancreatography. World J Gastroenterol. 2012;18(46):6843-9.

2. Clarke GA, Jacobson BC, Hammett RJ, Carr-Locke DL. The indications, utilization and safety of gastrointestinal endoscopy in and extremely elderly patient cohort. Endoscopy. 2001;33(7):580-4.

3. ASGE Standards of Practice Committee, Maple JT, Ben-Menachem T, Anderson MA, Appalaneni V, Banerjee S, Cash BD, et al. The role of endoscopy in the evaluation of suspected choledocholithiasis. Gastrointest Endosc. 2010;71(1):1-9.

4. Liu CL, Lo CM, Chan JK, Poon RT, Lam CM, Fan ST, et al. Detection of choledocholithiasis by EUS in acute pancreatitis: a prospective evaluation in 100 consecutive patients. Gastrointest Endosc. 2001;54(3):325-30.

5. Ney MV, Maluf-Filho F, Sakai P, Zilberstein B, Gama-Rodrigues |, Rosa $\mathrm{H}$. Echo-endoscopy versus endoscopic retrograde cholangiography for the diagnosis of choledocholithiasis: the influence of the size of the stone and diameter of the common bile duct. Arq Gastroenterol. 2005;42(4):239-43.

6. Demartines N, Eisner L, Schnabel K, Fried R, Zuber M, Harder F. Evaluation of magnetic resonance cholangiography in the management of bile duct stones. Arch Surg. 2000;135(2):148-52.

7. Sakai Y, Tsuyuguchi T, Sugiyama H, Nishikawa T, Tawada K, Saito M, et al. Current situation of endoscopic treatment for common bile duct stones. Hepatogastroenterology. 2012;59(118):1712-6.

8. Buscarini E, Tansini P, Vallisa D, Zambelli A, Buscarini L. EUS for suspected choledocholithiasis: do benefits outweigh costs? A prospective, controlled study. Gastrointest Endosc. 2003;57(4):510-8.

9. Stabuc B, Drobne D, Ferkolj I, Gruden A, lereb |, Kolar G, et al. Acute biliary pancreatitis: detection of common bile duct stones with endoscopic ultrasound. Eur J Gastroenterol Hepatol. 2008;20(12):1171-5.

10. Seo YR, Moon JH, Choi HJ, Kim DC, Lee TH, Cha SW, et al. Papillary balloon dilation is not itself a cause of post-endoscopic retrograde cholangiopancreatography pancreatitis; results of anterograde and retrograde papillary balloon dilation. J Gastroenterol Hepatol. 2013;28(8):1416-21.

11. Repiso A, Gómez-Rodríguez R, García-Vela A, Pérez-Grueso MJ, Martín $\mathrm{R}$, Romero $\mathrm{M}$, et al. Endosonographic examination of the common bile duct in patients with acute biliary pancreatitis. Rev Esp Enferm Dig. 2008;100(6):337-42.

12. Lévy P, Boruchowicz A, Hastier P, Pariente A, Thévenot T, Frossard JL, et al. Diagnostic criteria in predicting a biliary origin of acute pancreatitis in the era of endoscopic ultrasound: multicentre prospective evaluation of 213 patients. Pancreatology. 2005;5(4-5):450-6.

13. Fukino N, Oida T, Kawasaki A, Mimatsu K, Kuboi Y, Kano H, et al. Impaction of a lithotripsy basket during endoscopic lithotomy of a common bile duct stone. World J Gastroenterol. 2010;16(22):2832-4.

14. Petrov MS, Van Santvoort HC, Besselink MG, van der Heijden G], van Erpecum KJ, Gooszen HG. Early endoscopic retrograde cholangiopancreatography versus conservative management in acute biliary pancreatitis without cholangitis: a meta-analysis of randomized trials. Ann Surg. 2008;247(2):250-7. 